\title{
Pemodelan Nilai Data Gaya Berat Subduksi Pulau Jawa
}

\author{
Farid Hendra Pradana, Wien Lestari, dan Dwa Desa Warnana \\ Departemen Teknik Geofisika, Fakultas Teknik Sipil dan Perencanaan, Institut Teknologi Sepuluh \\ Nopember (ITS) \\ e-mail:wien.geofisika@gmail.com
}

\begin{abstract}
Abstrak-Salah satu metode geofisika yang dapat digunakan untuk memodelkan fitur geologi dalam, seperti subduksi, adalah metode gaya berat. Terdapat korelasi yang bersifat kuantitatif antara data gaya berat dan model geologi subduksi. Penelitian ini mengamati pengaruh bentukan dan persebaran densitas dari model geologi subduksi terhadap bentukan dan besar nilai data gaya berat, atau yang biasa disebut dengan forward modelling. Tujuan dari penelitian ini adalah untuk mengkarakterisasi efek yang muncul pada data gaya berat akibat dari bentuk model geologi subduksi di Pulau Jawa. Hasil yang didapatkan menunjukkan bahwa bentukan model subduksi yang sangat berpengaruh terhadap bentuk data gaya berat, dengan jarak antar titik sejauh satu kilometer, hanyalah model dengan kedalaman 0 hingga 15 kilometer. Model subduksi pada kedalaman 15 hingga dasar model hanya memengaruhi kecenderungan atau kemiringan profil data gaya berat.
\end{abstract}

Kata Kunci-Pemodelan Nilai Data Gaya Berat, Metode Gaya Berat, Subduksi Pulau Jawa.

\section{PENDAHULUAN}

$\mathrm{S}_{\mathrm{n}}$ ALAH satu metode geofisika yang dapat digunakan untuk memodelkan fitur geologi dalam, seperti subduksi, adalah metode gaya berat. Hal ini dibuktikan dari beberapa penelitian sebelumnya tentang pemodelan zona subduksi Pulau Jawa melalui data gaya berat yang selanjutnya diketahui beberapa informasi, seperti sudut inklinasi penunjaman lempeng samudera di Pulau Jawa bagian timur dan tengah berkisar antara $3.4^{0}-8.2^{0}$, kedalaman rata-rata batuan dasar tersier di Pulau Jawa adalah $2.7 \mathrm{~km}$, dan kedalaman rata-rata batas Mohorovicic di Pulau Jawa adalah 25.6 km [1]. Beberapa penelitian lain untuk memodelkan zona subduksi menggunakan data gaya berat juga telah dilakukan melalui proses inversi baik 2D maupun 3D [2]. Dari penelitianpenelitian tersebut dapat disimpulkan bahwa terdapat korelasi yang bersifat kuantitatif antara data gaya berat dan model geologi subduksi.

Apabila pada penelitian-penelitian sebelumnya dilakukan pengamatan ataupun perhitungan model geologi subduksi dari data gaya berat, yang biasa disebut dengan proses inversi, maka pada penelitian ini akan dilakukan pengamatan pada pengaruh model geologi subduksi terhadap data gaya berat, yang biasa disebut dengan proses forward modelling. Tujuan dari penelitian ini adalah untuk mengkarakterisasi efek yang muncul pada data gaya berat akibat dari bentuk model geologi subduksi di Pulau Jawa. Hasil dari penelitian ini diharapkan dapat menjadi acuan untuk mengetahui bentukan subduksi yang memungkinkan dari suatu bentukan data gaya berat tertentu.

\section{METODOLOGI PENELITIAN}

\section{A. Rancangan Penelitian}

Penelitian ini dimulai dengan mencari model subduksi Pulau Jawa dari referensi terkait. Model geologi subduksi tersebut kemudian akan dikondisikan terlebih dahulu sebelum dilakukan pemodelan. Pengondisian model subduksi meliputi proses dijitasi, smoothing, dan perpanjangan (ekstensi). Pemodelan dilakukan menggunakan algoritma Blakely yang menghitung gaya tarik vertikal dari suatu tubuh massa dengan nilai densitas tertentu pada suatu lokasi terhadap lokasi lainnya [3]. Setelah dilakukan pemodelan kedepan, maka akan dilakukan analisis terhadap data gaya berat yang dihasilkan terhadap model geologi subduksi. Rancangan penelitian diilustrasikan pada gambar 1 .

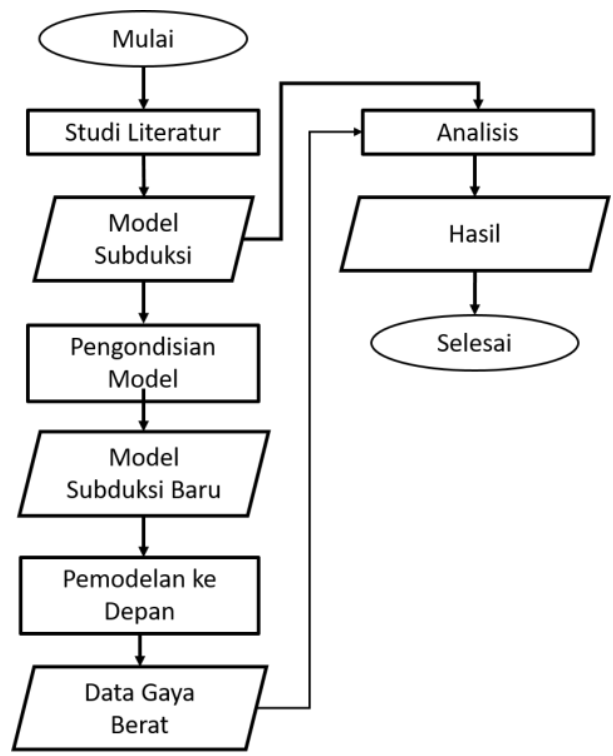

Gambar 1. Rancangan Penelitian

\section{B. Model Subduksi}

Model densitas subduksi I didapatkan dari penelitianpenelitian sebelumnya yang membahas tentang pemodelan subduksi Pulau Jawa. Model diambil dari Geophysical Journal International (2011) volume 184 dengan judul "Structural 
architecture of oceanic plateau subduction offshore Eastern Java and the potential implications for geohazard". Pada penelitian ini model subduksi diperoleh dari hasil tomografi metode seismik berupa waktu tempuh dan model kecepatan yang kemudian diubah menjadi nilai densitas melalui persamaan Gardner. Model densitas subduksi II didapatkan dari disertasi dengan judul "Tomographic investigation of the crust of central java, Indonesia"[4]. Dalam disertasi ini, model subduksi juga didapat dari metode tomografi seismik.

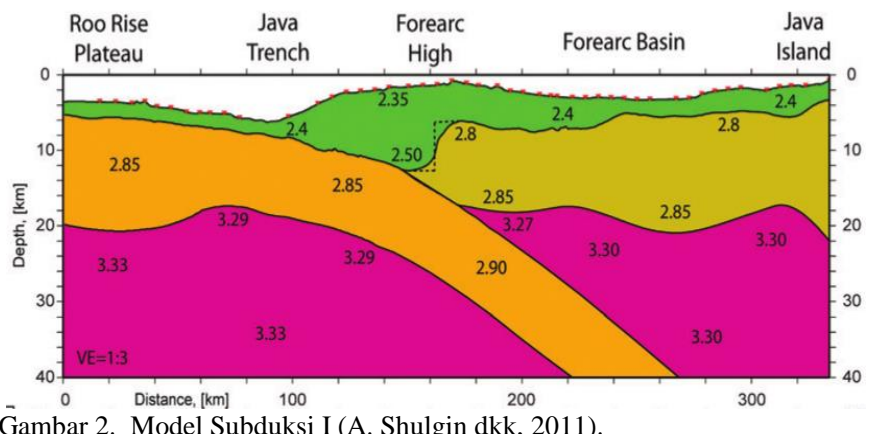

Gambar 2. Model Subduksi I (A. Shulgin dkk, 2011).

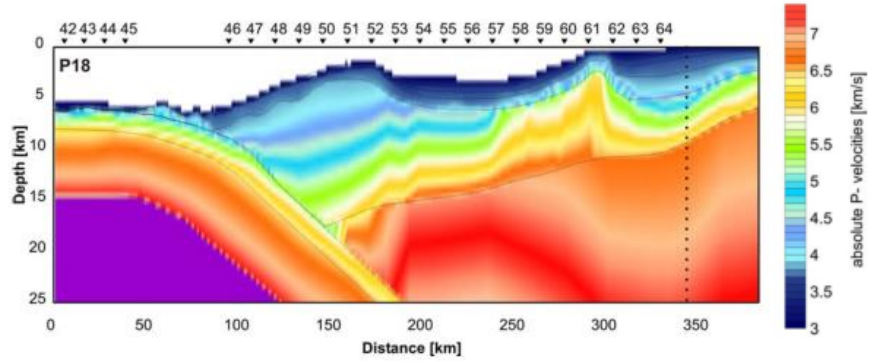

Gambar 3. Model Subduksi II (Wagner, D., 2007).

\section{Pengondisian Model}

Model densitas subduksi yang pada awalnya berupa gambar diubah menjadi kumpulan kisi segi empat yang bertautan (mesh grid) dengan nilai $x$ (lokasi horisontal), y (lokasi vertikal/kedalaman), dan $z$ (nilai densitas). Hasil konversi model gambar menjadi model mesh grid dapat dilihat pada gambar 4 dan 5 .

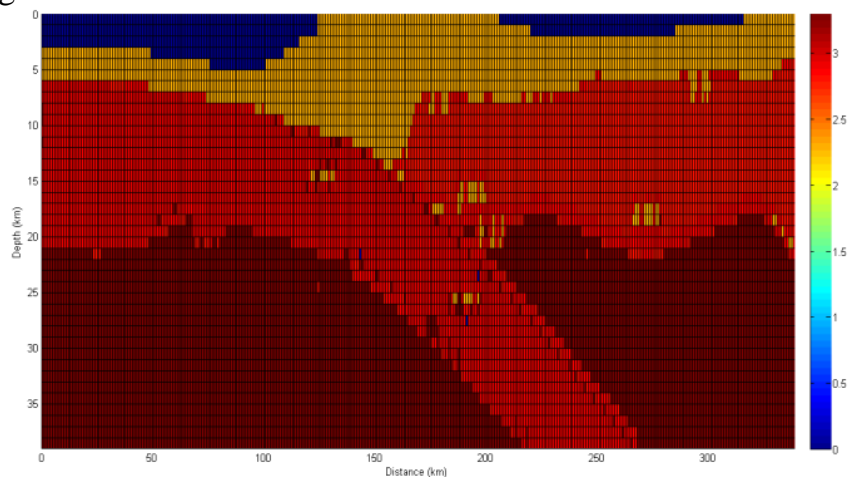

Gambar 4. Hasil Konversi Model Gambar Subduksi I menjadi Model Mesh Grid (xyz).

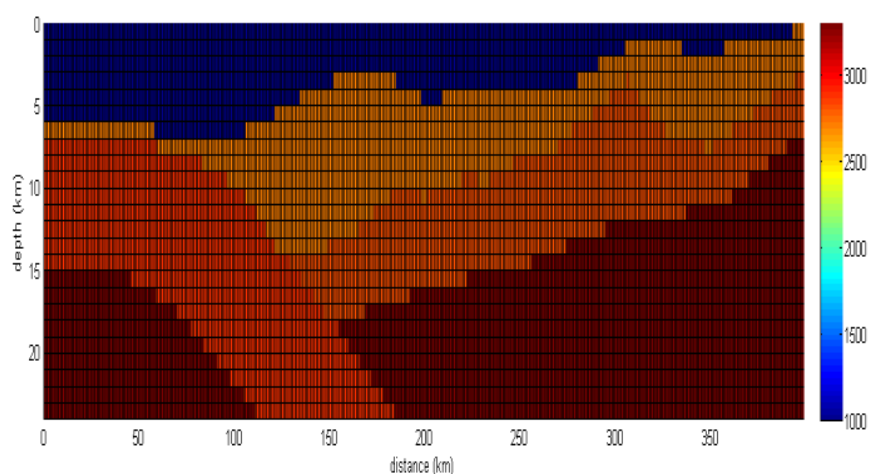

Gambar 5. Hasil Konversi Model Gambar Subduksi II menjadi Model Mesh Grid (xyz).

Model densitas yang telah diubah kedalam bentuk mesh grid dikondinisikan terlebih dahulu sebelum dilakukan pemodelan. Pengkondisian dilakukan dengan dua buah cara. Cara pertama adalah melakukan peoses moving average secara horisontal dan vertikal pada tiap kisi. Cara kedua adalah memperpanjang model pada sebelah kiri dan kanan dari model yang ingin dimodelkan ke depan. Densitas dari model perpanjangan tersebut didapatkan dari nilai mesh grid paling kiri dan paling kanan. Hasil dari pengondisian ini dapat dilihat pada gambar 6.

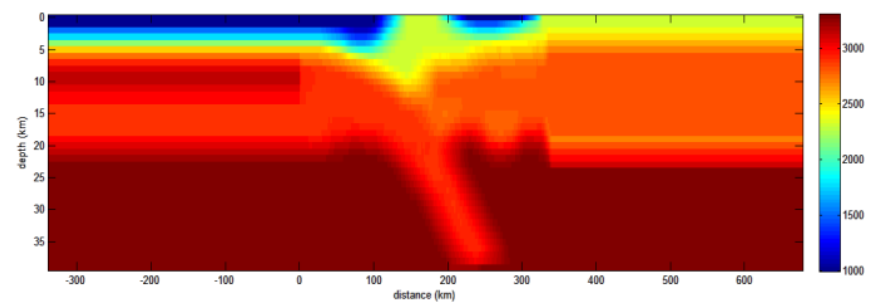

Gambar 6. Model Subduksi I yang Telah Dikondisikan.

\section{Pemodelan}

Model yang telah dikondisikan akan dihitung satu per satu gaya tarik setiap elemen penyusunnya terhadap lokasi yang ditentukan, yaitu permukaan. Hasil yang didapat adalah nilai gaya tarik gravitasi dari model densitas dalam satuan miligal pada lokasi yang diinginkan dalam bentuk profil gaya berat. Hasil dari pemodelan dapat dilihat pada gambar 7 dan 8 .

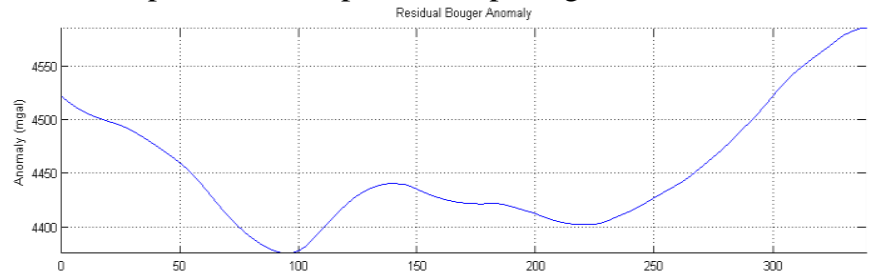

Gambar 7. Data Gaya Berat Hasil Pemodelan Model Subduksi I

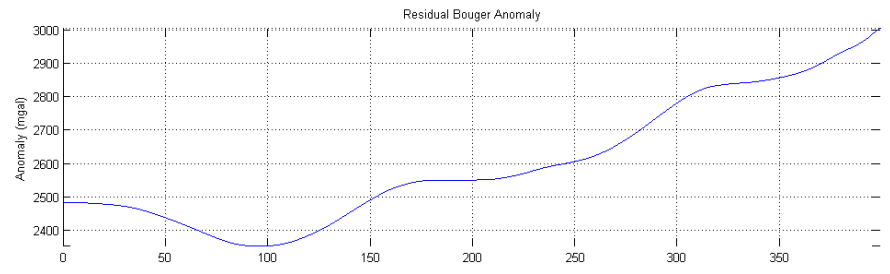

Gambar 8. Data Gaya Berat Hasil Pemodelan Model Subduksi II 


\section{HASIL DAN PEMBAHASAN}

\section{A. Model Subduksi I}

Model Subduksi I memiliki bentangan horisontal sepanjang 340 kilometer dan bentangan vertikal sepanjang 40 kilometer dengan variasi nilai massa jenis berkisar antara 1 gram $/ \mathrm{cc}$ hingga $3.3 \mathrm{gram} / \mathrm{cc}$. Nilai data gaya berat yang dihasilkan dari pemodelan model subduksi bervariasi pada rentang 4350 hingga 4600 mgal. Bentukan profil data gaya berat dipengaruhi baik oleh geometri ,secara horisintal dan vertikal, maupun kontras densitas dari model subduksi tersebut.

Efek paling signifikan pada bentukan data gaya berat dipengaruhi oleh model subduksi pada rentang kedalaman 0 hingga 15 kilometer. Bentukan terdalam yang masih berpengaruh secara signifikan terhadap bentukan data gaya berat terletak pada kilometer 170 dan kedalaman 15 kilometer. Bentuk model subduksi pada kedalaman 15 hingga 40 kilometer tidak terlalu berpengaruh pada bentukan data gaya berat.
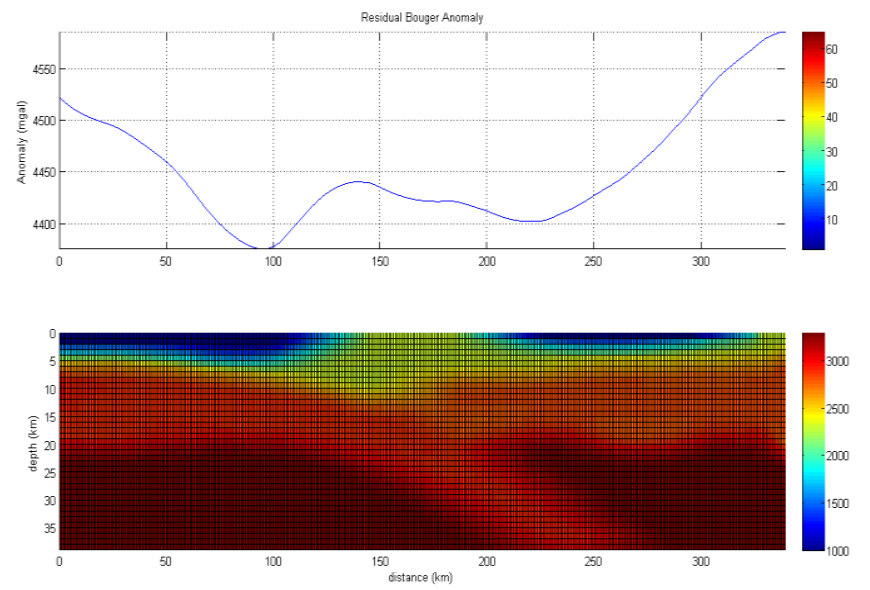

Gambar 9. Perbandingan Model Subduksi I dan Data Gaya Berat Hasil Pemodelan

\section{B. Modul Subduksi II}

Model Subduksi II memiliki bentangan horisontal sepanjang 400 kilometer dan bentangan vertikal sepanjang 25 kilometer dengan variasi nilai massa jenis berkisar antara 1 gram/cc hingga $3.3 \mathrm{gram} / \mathrm{cc}$. Nilai data gaya berat yang dihasilkan dari pemodelan model subduksi bervariasi pada rentang 2200 hingga 2600 mgal. Bentukan profil data gaya berat dipengaruhi baik oleh geometri, secara horisintal dan vertikal, maupun kontras densitas dari model subduksi tersebut.

Efek paling signifikan pada bentukan data gaya berat dipengaruhi oleh model subduksi pada rentang kedalaman 0 hingga 15 kilometer. Bentukan terdalam yang masih berpengaruh secara signifikan terhadap bentukan data gaya berat terletak pada kedalaman 15 kilometer. Bentuk model subduksi pada kedalaman 15 hingga 25 kilometer tidak terlalu berpengaruh pada bentukan data gaya berat.

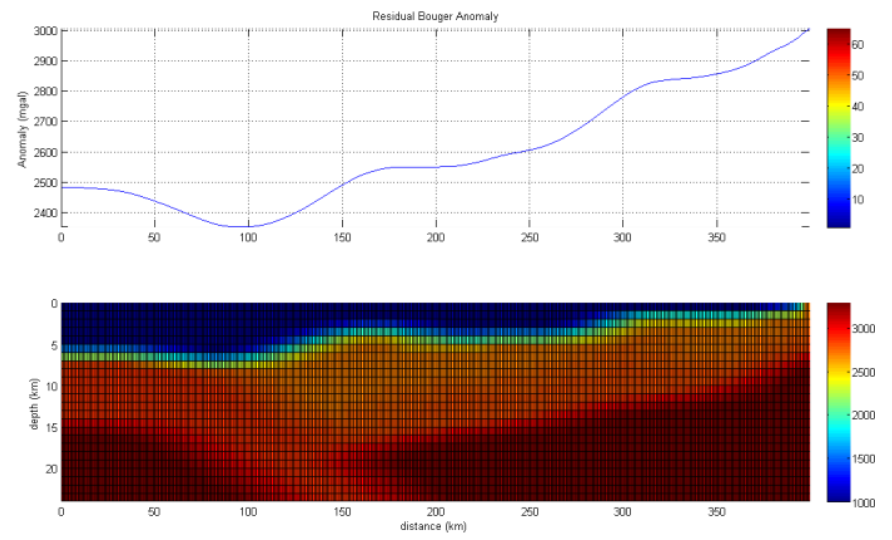

Gambar 10. Perbandingan Model Subduksi II dan Data Gaya Berat Hasil Pemodelan

\section{KESIMPULAN}

Berdasarkan penelitian yang telah dilaksanakan dapat diambil kesimpulan bahwa bentukan model subduksi yang sangat berpengaruh terhadap bentuk data gaya berat ,dengan jarak antar titik sejauh satu kilometer, hanyalah model dengan kedalaman 0 hingga 15 kilometer. Model subduksi pada kedalaman 15 hingga dasar model hanya memengaruhi kecenderungan atau kemiringan profil data gaya berat.

\section{DAFTAR PUSTAKA}

[1] R. D. Indriana, "Estimasi Ketebalan Sedimen dan Kedalaman Diskontinuitas Mohorovicic Daerah Jawa Timur dengan Analisis Power Spectrum Data Anomlai Gravitasi," Berk. Fis., vol. 11, no. 2, pp. 67-74, 2008.

[2] M. R. Setiawan, "Pemodelan Struktur Bawah Permukaan Zona Subduksi dan Busur Gunung Api Jawa Timur Berdasarkan Analisis Data Gravitasi," UGM Yogyakarta, 2015.

[3] R. . Blakely, "Potential Theory in Gravity and Magnetic Applications," Cambridge Univ., 1996.

[4] D. Wagner, "Tomographic investigation of the crust of central java, Indonesia,dkk," 2007. 